\title{
Minat Mahasiswa Akuntansi Memperoleh Sertifikasi Chartered Accountant
}

\author{
Andrea Diva Ananda1 \\ Fakultas Ekonomi dan Bisnis \\ Universitas Udayana, Indonesia
}

\author{
Ni Made Dwi Ratnadi \\ Fakultas Ekonomi dan Bisnis \\ Universitas Udayana, Indonesia
}

\begin{abstract}
Surel : andreadiva9a@gmail.com
\section{ABSTRAK}

Penelitian ini bertujuan untuk mengetahui faktor-faktor yang memengaruhi minat mahasiswa akuntansi memperoleh sertifikasi CA. Theory of planned behavior digunakan sebagai landasan teori untuk menjelaskan pengaruh sikap terhadap perilaku, norma subjektif, dan kontrol perilaku persepsian pada minat memperoleh sertifikasi CA. Tingkat pengetahuan juga merupakan salah satu faktor informasi yang dapat memengaruhi niat berperilaku. Jumlah sampel yang digunakan dalam penelitian ini sebanyak 168 responden dengan metode penentuan sampel yaitu metode simple random sampling. Pengumpulan data dilakukan dengan metode kuesioner. Teknik analisis yang digunakan adalah analisis regresi linear berganda. Hasil analisis mengindikasikan bahwa sikap terhadap perilaku, norma subjektif, dan kontrol perilaku persepsian berpengaruh positif pada minat mahasiswa akuntansi memperoleh sertifikasi CA. Sedangkan tingkat pengetahuan tidak berpengaruh pada minat mahasiswa akuntansi memperoleh sertifikasi CA.
\end{abstract}

Kata Kunci: $\quad$ Minat; Sikap Terhadap Perilaku; Norma Subjektif; Kontrol Perilaku Persepsian; Pengetahuan.

\section{Interests in Accounting Students Obtaining Chartered Accountant Certification}

\begin{abstract}
This research aimed to determine the factors affecting accounting students' interest in obtaining the CA certification. The theory of planned behavior is used as a theoretical basis to explain the effect of attitudes toward behavior, subjective norms, and perceived behavioral control on the interest in obtaining CA certification. The level of knowledge is also one of the information factors that can influence behavior intention. The number of samples used in this study was 168 respondents to determine the sample, namely the simple random sampling method. Data were collected using a questionnaire. The analysis technique used is multiple linear regression analysis. The analysis results indicate that attitudes toward behavior, subjective norms, and perceived behavioral control positively affect accounting students' interest to obtain CA certification. Meanwhile, the level of knowledge about CA does not affect accounting students' interest to obtain CA certification.
\end{abstract}

Keywords: Interest; Attitudes Toward Behavior; Subjective Norms; Perceived Behavioral Control; Knowledge.

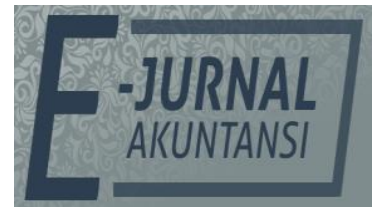

e-ISSN 2302-8556

Vol. 31 No. 9

Denpasar, September 2021

Hal. 2169-2181

DOI:

10.24843/EJA.2021.v31.i09.p02

PENGUTIPAN:

Ananda, A.D., \& Ratnadi,

N.M.D. (2021). Minat

Mahasiswa Akuntansi

Memperoleh Sertifikasi

Chartered Accountant. EJurnal Akuntansi, 31(9), 2169-

2181

RIWAYAT ARTIKEL:

Artikel Masuk:

30 November 2020

Artikel Diterima: 15 Februari 2021

Artikel dapat diakses : https://ojs.unud.ac.id/index.php/Akuntansi/index 


\section{PENDAHULUAN}

Perubahan dan kemajuan yang sangat pesat tercermin di era globalisasi saat ini. Dalam era globalisasi, persaingan semakin ketat dan diperlukan SDM dengan keunggulan kompetitifnya agar dapat bersaing menghadapi tantangan profesi dalam perekonomian global (Agusalim \& Pohan, 2017) dan (Alam et al., 2019). Akuntan merupakan salah satu profesi yang sangat dibutuhkan dalam dunia perekonomian dan tenaga kerja akuntan profesional menjadi persaingan bebas antar negara dalam perekonomian global (Gayatri et al., 2016). Keahlian akuntan profesional diakui sebagai komponen penting infrastruktur kelembagaan suatu negara dan berperan penting untuk membantu menjaga sistem akuntansi yang dinamis (Owusu et al., 2018), (Grace N \& Ekele, 2018), (Brouard et al., 2016), (Dalci \& Ozyapici, 2016), dan (Thorne, 2016). Ikatan Akuntan Indonesia meluncurkan kualifikasi akuntan profesional dengan sebutan Chartered Accountant yang diakui secara internasional. Sertifikasi akuntan profesional dibutuhkan seluruh dunia untuk meningkatkan perekonomian dan mutu informasi di bidang keuangan (Akter \& Siraj, 2018). Perkembangan keanggotaan IAI disajikan dalam Tabel 1.

Tabel 1. Perkembangan Keanggotaan IAI 2015-2018

\begin{tabular}{lllll}
\hline Keanggotaan IAI & 2015 & 2016 & 2017 & 2018 \\
\hline Anggota Utama & 17,340 & 18,092 & 19,770 & 19,938 \\
Anggota Madya & 7,096 & 7,203 & 5,164 & 5,779 \\
Anggota Muda & 3,897 & 2,120 & 3,045 & 2,802 \\
Jumlah & 28,333 & 27,415 & 27,979 & 28,519 \\
\hline
\end{tabular}

Sumber: Ikatan Akuntan Indonesia, 2018

Tabel 1, menjelaskan bahwa keanggotaan IAI mencatatkan perkembangan yang signifikan. Jumlah anggota IAI terbanyak tercatat pada tahun 2018 sejumlah 28,519 orang, yang terdiri dari anggota utama sebagai pemegang sertifikasi Chartered Accountant sejumlah 19,938 orang, anggota madya sejumlah 5,779 orang, dan anggota muda sejumlah 2.802 orang. Jumlah anggota utama sebagai pemegang sertifikasi Chartered Accountant dari tahun 2015-2018 mengalami peningkatan setiap tahunnya.

Peningkatan jumlah akuntan profesional di Indonesia dengan sebutan Chartered Accountant masih relatif sedikit dibandingkan dengan jumlah akuntan profesional beberapa negara di Asia Tenggara yang tentunya Indonesia berpotensi diserbu oleh akuntan handal lainnya jika kondisi ini tidak diperhatikan lebih lanjut (Srirejeki et al., 2019). Pemerintah memberikan perhatian yang besar terhadap profesi akuntan dengan diterbitkannya PMK No. 25/PMK.01/2014 yang selanjutnya digantikan oleh PMK No. 216/PMK.01/2017 tentang Akuntan Beregister Negara. Kriteria mengikuti ujian CA dijelaskan dalam PMK No. 216/PMK.01/2017 pasal 5 ayat 3, salah satunya yaitu minimal berpendidikan DIV atau S1 akuntansi dengan atau tanpa mengikuti PPAk terlebih dahulu (PMK, 2017). PPAk Fakultas Ekonomi dan Bisnis Universitas Udayana menjalin kerjasama dengan IAI dan mengakomodir mahasiswa yang mengikuti ujian CA sebagai bentuk pengimplementasian Permendikbud 153/2014 tentang PPAk dalam penyelenggaraan ujian sertifikasi CA. 
Profesi akuntansi terancam oleh kurangnya lulusan yang berkualitas secara global (Pratama, 2017) dan (Dewi et al., 2018). Hal ini terjadi karena banyak lulusan akuntansi yang langsung terjun ke dunia kerja sebelum memperoleh sertifikasi akuntan profesional dengan sebutan CA (Wen et al., 2015). Pentingnya sertifikasi CA untuk lulusan mahasiswa akuntansi yaitu untuk mewujudkan terciptanya akuntan profesional dan memiliki daya saing di tingkat global (Hasim et al., 2020), (Ulfah et al., 2019), dan (Wardani \& Januarti, 2015). Kebutuhan pasar akan jasa akuntan profesional belum tercukupi oleh jumlah akuntan teregister khususnya pemegang sertifikasi CA di Indonesia yang tidak sebanding dengan jumlah lulusan sarjana akuntansi yang selalu meningkat setiap tahunnya (Nisa, 2019a). Perilaku seseorang terbentuk dari adanya intensi (niat). Semakin kuat niat dalam berperilaku, semakin besar juga kemungkinan kinerjanya (Ajzen, 1991). Perspektif keyakinan atau kepercayaan merupakan fondasi yang dapat mempengaruhi tingkah laku seseorang secara spesifik yang dijelaskan dalam theory of planned behavior (Seni \& Ratnadi, 2017). Minat perilaku diprediksi oleh sikap pada perilaku, norma subjektif, dan kontrol perilaku. Pengetahuan juga merupakan faktor penentu bagaimana manusia berpikir, merasa dan bertindak. Pola pikir seseorang atau kemampuan untuk berpikir dan bertindak secara terarah dan efektif dipengaruhi oleh tingkat pengetahuan yang dimiliki dan dikuasainya (Kusumastuti \& Waluyo, 2013). Seseorang dapat mengambil keputusan dengan cepat, tepat dan mudah berdasarkan pada pengetahuan yang dimilikinya.

Relatif sedikitnya penelitian mengenai minat untuk memperoleh sertifikasi CA yang sangat berguna bagi para lulusan akuntansi sebagai bekal untuk menghadapi tantangan profesi akuntansi dalam perekonomian global menyebabkan penelitian ini melakukan pengujian kembali pengaruh sikap terhadap perilaku, norma subjektif, kontrol perilaku persepsian pada minat mahasiswa memperoleh sertifikasi CA dengan menambahkan variabel tingkat pengetahuan mengenai CA. Variabel tingkat pengetahuan yang ditambahkan merupakan salah satu faktor informasi yang juga dapat mempengaruhi niat dalam berperilaku. Penambahan faktor informasi yang merupakan faktor lain dalam mempengaruhi niat berperilaku selain dari faktor pribadi dan sosial tersebut untuk melengkapi kelemahan dari theory of planned behavior yang menjelaskan niat berperilaku manusia hanya berdasarkan faktor pribadi dan faktor sosial, sehingga menyebabkan penelitian ini akan relatif berbeda dari penelitian-penelitian sebelumnya.

Theory of planned behavior menjelaskan bahwa sikap terhadap perilaku merupakan keyakinan individu terhadap hasil dari suatu perilaku yang membentuk pandangan, sikap perasaan positif atau negatif pada suatu objek, orang atau peristiwa yang menentukan kecenderungan dalam berperilaku (Ajzen, 1991). Sikap tersebut timbul dari adanya evaluasi individu terhadap konsekuensi positif atau negatif (Outcome evaluation) yang didapatkan dari sebuah perilaku tertentu (behavioral beliefs) (Islamylia \& Mutia, 2016). Seseorang yang memiliki sikap positif atau tanggapan positif memandang sertifikasi CA dapat memberikan keuntungan. Hal ini menunjukkan bahwa seorang individu yang berpandangan baik terhadap sertifikasi CA antara lain memiliki 
kepercayaan atau keyakinan dengan memperoleh sertifikasi CA akan membawa dampak positif maka dapat meningkatkan niat memperoleh sertifikasi CA.

Hasil penelitian (Nisa, 2019a) menemukan bahwa sikap terhadap perilaku berpengaruh pada minat mahasiswa memperoleh sertifikasi CA. Hasil penelitian tersebut searah dengan hasil penelitian (Dewi et al., 2018), (Solikhah, 2014) dan (Sumaryono \& Sukanti, 2016). Kondisi tersebut menjelaskan bahwa semakin baik cara pandang seseorang terhadap sertifikasi CA, maka minat seseorang semakin meningkat untuk memperoleh sertifikasi CA. Berdasarkan uraian tersebut, maka dapat dirumuskan hipotesis sebagai berikut.

$\mathrm{H}_{1}$ : Semakin tinggi sikap terhadap perilaku, maka semakin tinggi minat mahasiswa akuntansi memperoleh sertifikasi CA.

Theory of planned behavior menjelaskan bahwa norma subjektif adalah suatu pandangan seseorang terhadap pengaruh tekanan sosial dari orang terdekat untuk melakukan suatu perilaku ataupun tidak (Ajzen, 1991). Norma subjektif dipengaruhi oleh keyakinan normatif (normative beliefs) dan motivasi dari orang lain yang ikut terlibat di dalamnya. Lingkungan memiliki peran yang sangat penting dalam proses pengambilan keputusan suatu individu. Minat seorang individu akan lebih tinggi memperoleh sertifikasi CA apabila individu tersebut berada dalam lingkungan yang memiliki pengaruh positif terhadap sertifikasi CA dibandingkan dengan seorang individu dalam lingkungan yang kurang setuju untuk memperoleh sertifikasi CA sehingga minatnya akan lebih rendah untuk memperoleh sertifikasi CA.

Hasil penelitian (Mihartinah \& Corynata, 2018) menunjukkan bahwa norma subjektif berpengaruh positif terhadap minat mahasiswa memperoleh sertifikasi CA. Hasil penelitian tersebut searah dengan hasil penelitian (Bekoe et al., 2018), (Permata et al., 2019), (Solikhah, 2014), (Sumaryono \& Sukanti, 2016), dan (Wardani \& Januarti, 2015). Kondisi tersebut menjelaskan semakin banyak dukungan dari orang terdekat dan juga lingkungan yang mendorong untuk memperoleh sertifikasi CA, maka semakin tinggi niat individu untuk memperoleh sertifikasi CA. Berdasarkan uraian tersebut, maka dapat dirumuskan hipotesis sebagai berikut.

$\mathrm{H}_{2}$ : Semakin tinggi kepercayaan terhadap pengaruh sosial yang dirasakan, maka semakin tinggi minat mahasiswa akuntansi memperoleh sertifikasi CA.

Theory of planned behavior menjelaskan bahwa kontrol perilaku persepsian adalah persepsi seseorang terhadap faktor-faktor yang dapat memudahkan atau menghambat dalam melakukan perilaku sehubungan dengan perspektif keyakinan ada atau tidaknya sumber daya dan kesempatan yang dibutuhkan (control beliefs) (Ajzen, 1991). Kontrol berupa keterampilan, kesempatan yang dimiliki untuk menunjukkan suatu perilaku, dan tersedianya sumber daya mempengaruhi tindakan seseorang. Seseorang dapat memiliki tekad yang kuat untuk menunjukkan suatu perilaku yakni kemampuan untuk memperoleh sertifikasi CA apabila mempunyai kontrol-kontrol tersebut. Semakin mudah untuk memperoleh sertifikasi CA, maka semakin meningkat juga niat seseorang memperoleh sertifikasi CA, begitu juga sebaliknya.

Hasil penelitian (Umar \& Bello, 2019) menunjukkan bahwa kontrol perilaku persepsian berpengaruh pada minat individu memperoleh sertifikasi CA. Hasil penelitian tersebut searah dengan hasil penelitian (Srirejeki et al., 2019); 
(Sumaryono \& Sukanti, 2016) dan (Solikhah, 2014). Kondisi tersebut menjelaskan bahwa sedikitnya hambatan memperoleh sertifikasi CA, maka niat seseorang akan lebih tinggi untuk memperoleh sertifikasi CA. Berdasarkan uraian tersebut, maka dapat dirumuskan hipotesis sebagai berikut.

$\mathrm{H}_{3}$ : Semakin tinggi tingkat kontrol perilaku persepsian, maka semakin tinggi minat mahasiswa akuntansi memperoleh sertifikasi CA.

Informasi yang harus diketahui oleh seseorang untuk meningkatkan minat dalam memperoleh sertifikasi CA yaitu tentang Chartered Accountant (CA). Seseorang yang memiliki pengetahuan tentang CA dan mengetahui informasi dari isi PMK No. 216/PMK.01/2017 tentang Akuntan Beregister Negara terkait CA akan lebih memahami manfaat dari profesionalisme seseorang dalam bidang akuntansi untuk perkembangan karirnya serta mengetahui cara maupun syarat yang diperlukan untuk memperoleh sertifikasi CA (Dewi et al., 2018) dan (Nisa, 2019b).

Hasil penelitian (Aginsyah, 2018) dan (Ticoi \& Albu, 2018) menunjukkan bahwa pengetahuan berpengaruh positif signifikan terhadap minat mahasiswa akuntansi untuk mengikuti sertifikasi CA. Hasil penelitian tersebut searah dengan hasil penelitian (Dewi et al., 2018). Kondisi tersebut menjelaskan bahwa semakin tinggi atau luas tingkat pengetahuan yang dimiliki seseorang terhadap sertifikasi CA, maka niat seseorang akan semakin tinggi untuk memperoleh sertifikasi CA. Berdasarkan uraian tersebut, maka dapat dirumuskan hipotesis sebagai berikut.

$\mathrm{H}_{4}$ : Semakin tinggi tingkat pengetahuan mengenai $\mathrm{CA}$, maka semakin tinggi minat mahasiswa akuntansi memperoleh sertifikasi CA.

\section{METODE PENELITIAN}

Penelitian ini menggunakan pendekatan kuantitatif yang berbentuk asosiatif, karena menjelaskan hubungan antara variabel satu dengan variabel lainnya (Sugiyono, 2019:16). Fakultas Ekonomi dan Bisnis Universitas Udayana merupakan lokasi yang digunakan dalam penelitian. Alasan pemilihan lokasi ini dikarenakan FEB UNUD merupakan perguruan tinggi penyelenggara PPAk di Bali yang mengakomodir mahasiswa untuk mengikuti ujian CA. Populasi yang digunakan adalah mahasiswa S1 Akuntansi reguler angkatan 2017 FEB UNUD yang berjumlah 289 mahasiswa, karena penelitian ini menganalisis mahasiswa program studi akuntansi semester 7 tahun ajaran 2020/2021 yang merupakan tahun terakhir dalam perkuliahan dan setelah menyelesaikan program S1 dianggap telah memiliki rencana ke depan untuk berkarir dalam dunia kerja serta memiliki gambaran atau pengetahuan mengenai profesi seorang akuntan publik. Berdasarkan perhitungan rumus slovin, jumlah sampel yang digunakan dalam penelitian adalah 168 mahasiswa. Sampel yang diambil menggunakan teknik probability sampling yaitu simple random sampling. Metode pengumpulan data yang digunakan yaitu dengan menyebarkan kuesioner. Analisis regresi linear berganda digunakan untuk mengetahui hubungan secara linear antara variabel bebas dengan variabel terikat, yakni pengaruh sikap terhadap perilaku $\left(X_{1}\right)$, norma subjektif $\left(X_{2}\right)$, kontrol perilaku persepsian $\left(X_{3}\right)$, tingkat pengetahuan $\left(\mathrm{X}_{4}\right)$ pada minat mahasiswa memperoleh $\mathrm{CA}(\mathrm{Y})$. Model persamaan analisis regresi linear berganda ditunjukkan oleh persamaan berikut. 
$Y=\alpha+\beta_{1} X_{1}+\beta_{2} X_{2}+\beta_{3} X_{3}+\beta_{4} X_{4}+\varepsilon$

Keterangan:

$\mathrm{Y}=$ Minat memperoleh Sertifikasi CA

$\mathrm{a} \quad=$ Konstanta

$\beta_{1}-\beta_{4}=$ Koefisien Regresi

$\mathrm{X}_{1}=$ Sikap Terhadap Perilaku

$\mathrm{X}_{2}=$ Norma Subjektif

$X_{3} \quad=$ Kontrol Perilaku Persepsian

$\mathrm{X}_{4}=$ Tingkat Pengetahuan Mengenai CA

$\varepsilon \quad=$ Standar error

\section{HASIL DAN PEMBAHASAN}

Statistik deskriptif memberikan suatu gambaran atau deskripsi suatu data yang dilihat dari nilai rata-rata (mean), minimum (min), maksimum (max), serta deviasi standar (standard deviation) pada setiap variabel dalam penelitian, tanpa adanya maksud untuk menarik kesimpulan. Hasil statistik deskriptif disajikan dalam Tabel 2.

Tabel 2. Hasil Statistik Deskriptif

\begin{tabular}{lccccc}
\hline \multicolumn{1}{c}{ Variabel } & $\mathrm{N}$ & Minimum & Maximum & Mean & $\begin{array}{c}\text { Std. } \\
\text { Devitiation }\end{array}$ \\
\hline Sikap Terhadap Perilaku & 168 & 20 & 32 & 26,230 & 3,026 \\
Norma Subjektif & 168 & 12 & 24 & 17,770 & 2,877 \\
Kontrol Perilaku & & & & & \\
Persepsian & 168 & 8 & 12 & 9,980 & 1,231 \\
Tingkat Pengetahuan & 168 & 8 & 16 & 11,540 & 1,831 \\
Minat Memperoleh CA & 168 & 10 & 16 & 12,320 & 1,521 \\
\hline
\end{tabular}

Sumber: Data Penelitian, 2020

Variabel sikap terhadap perilaku $\left(X_{1}\right)$ memiliki nilai minimum (min) sebesar 20 yang berarti adanya responden menjawab tidak setuju dan tidak memiliki tanggapan positif pada sertifikasi CA. Nilai maksimum (max) sebesar 32 yang berarti adanya responden menjawab sangat setuju dan memiliki tanggapan positif atau pandangan yang baik pada sertifikasi CA. Sikap terhadap perilaku menunjukkan nilai rata-rata (mean) sebesar 26,23 yang mengindikasikan bahwa rata-rata responden cenderung menjawab setuju.

Variabel norma subjektif $\left(X_{2}\right)$ memiliki nilai minimum (min) sebesar 12 yang berarti adanya responden menjawab tidak setuju. Nilai maksimum (max) sebesar 24 yang berarti adanya responden menjawab sangat setuju, hal ini bermakna terdapat responden yang memiliki keyakinan bahwa minat memperoleh sertifikasi CA sangat dipengaruhi oleh keluarga, teman, dan dosen. Norma subjektif menunjukkan nilai rata-rata (mean) sebesar 17,77 yang mengindikasikan bahwa rata-rata responden cenderung menjawab setuju.

Variabel kontrol perilaku persepsian $\left(\mathrm{X}_{3}\right)$ memiliki nilai minimum $(\mathrm{min})$ sebesar 8 yang berarti adanya responden menjawab tidak setuju. Nilai maksimum (max) sebesar 12 yang berarti terdapat responden menjawab sangat setuju. Hal ini bermakna terdapat responden yang yakin bahwa sedikitnya atau tidak ada hambatan yang dirasakan dalam memperoleh sertifikasi CA. Kontrol 
perilaku persepsian menunjukkan nilai rata-rata (mean) sebesar 9,98 yang mengindikasikan bahwa rata-rata responden cenderung menjawab setuju.

Variabel tingkat pengetahuan $\left(\mathrm{X}_{4}\right)$ memiliki nilai minimum $(\mathrm{min})$ sebesar 8 yang berarti adanya responden menjawab tidak setuju. Nilai maksimum (max) sebesar 16 yang berarti adanya responden menjawab sangat setuju. Tingkat pengetahuan menunjukkan nilai rata-rata (mean) sebesar 11,54 yang mengindikasikan bahwa rata-rata responden cenderung menjawab setuju.

Variabel minat $(\mathrm{Y})$ memiliki nilai minimum $(\mathrm{min})$ sebesar 10 yang berarti adanya responden menjawab tidak setuju. Nilai maksimum (max) sebesar 16 yang berarti adanya responden menjawab sangat setuju. Minat menunjukkan nilai rata-rata (mean) sebesar 12,32 yang mengindikasikan bahwa rata-rata responden cenderung menjawab setuju. Teknik analisis data yang digunakan yaitu analisis regresi linear berganda. Hasil analisis regresi linear berganda disajikan dalam Tabel 3.

Tabel 3. Hasil Analisis Regresi Linear Berganda

\begin{tabular}{|c|c|c|c|c|c|}
\hline & \multirow{2}{*}{ Model } & \multicolumn{2}{|c|}{ Unstandardized Coefficients } & \multirow{2}{*}{$\mathrm{t}$} & \multirow{2}{*}{ Sig. } \\
\hline & & B & Std. Error & & \\
\hline \multirow[t]{5}{*}{1} & (Constant) & 2,771 & 1,196 & 2,317 & 0,022 \\
\hline & Sikap Terhadap Perilaku $\left(X_{1}\right)$ & 0,150 & 0,035 & 4,344 & 0,000 \\
\hline & Norma Subjektif $\left(X_{2}\right)$ & 0,146 & 0,037 & 3,898 & 0,000 \\
\hline & Kontrol Perilaku Persepsian $\left(X_{3}\right)$ & 0,180 & 0,083 & 2,174 & 0,031 \\
\hline & Tingkat Pengetahuan $\left(\mathrm{X}_{4}\right)$ & 0,105 & 0,057 & 1,839 & 0,068 \\
\hline \multicolumn{2}{|c|}{$R$ Square } & $: 0,310$ & & & \\
\hline \multicolumn{2}{|c|}{ Adjusted R Square } & :0,293 & & & \\
\hline \multicolumn{2}{|c|}{ F Statistik } & $: 18,288$ & & & \\
\hline \multicolumn{2}{|c|}{ Signifikansi } & $: 0,000$ & & & \\
\hline
\end{tabular}

Sumber: Data Penelitian, 2020

Berdasarkan hasil analisis yang disajikan pada Tabel 3, diperoleh suatu persamaan regresi sebagai berikut.

$$
\mathrm{Y}=2,771+0,150 \mathrm{X}_{1}+0,146 \mathrm{X}_{2}+0,180 \mathrm{X}_{3}+0,105 \mathrm{X}_{4}
$$

Hasil uji koefisien determinasi dengan Adjusted $\mathrm{R}^{2}$ yang tersaji dalam Tabel 3, menunjukkan bahwa nilai dari Adjusted $\mathrm{R}^{2}$ adalah sebesar 0,293 atau 29,3 persen. Hal ini berarti bahwa sebesar 29,3 persen variasi minat mahasiswa memperoleh CA dipengaruhi oleh variasi sikap terhadap perilaku, norma subjektif, kontrol perilaku persepsian, dan tingkat pengetahuan, sedangkan sisanya sebesar 70,7 persen dipengaruhi oleh variabel lain yang tidak dijelaskan dalam model penelitian ini.

Hasil uji kelayakan model (Uji F) yang tersaji pada Tabel 3, menyatakan bahwa nilai $F_{\text {hitung }}$ sebesar 18,288 dengan signifikansi sebesar 0,000 . Hal ini berarti bahwa signifikansi pada uji $\mathrm{F}$ nilainya lebih kecil dari 0,05 , sehingga dapat disimpulkan bahwa model regresi yang dibuat layak digunakan sebagai alat analisis untuk menguji pengaruh variabel independen terhadap variabel dependen. Nilai $t_{\text {hitung }}$ pada variabel sikap terhadap perilaku sebesar 4,344 dengan nilai signifikansi 0,000 yang lebih kecil dari 0,05 (5 persen). Koefisien regresi bernilai positif sebesar 0,150. Hal ini berarti sikap terhadap perilaku berpengaruh positif terhadap minat memperoleh sertifikasi CA. Berdasarkan hal 
tersebut mengindikasikan bahwa $\mathrm{H}_{1}$ diterima. Nilai $t_{\text {hitung }}$ pada variabel norma subjektif sebesar 3,898 dengan nilai signifikansi 0,000 yang lebih kecil dari 0,05 (5 persen). Koefisien regresi bernilai positif sebesar 0,146. Hal ini berarti norma subjektif berpengaruh positif pada minat memperoleh CA. Berdasarkan hal tersebut mengindikasikan bahwa $\mathrm{H}_{2}$ diterima.

Nilai $t_{\text {hitung }}$ pada variabel kontrol perilaku persepsian sebesar 2,174 dengan nilai signifikansi 0,031 yang lebih kecil dari 0,05 (5 persen). Koefisien regresi bernilai positif sebesar 0,180. Hal ini berarti kontrol perilaku persepsian berpengaruh positif pada minat memperoleh CA. Berdasarkan hal tersebut mengindikasikan bahwa $\mathrm{H}_{3}$ diterima. Nilai thitung pada variabel tingkat pengetahuan sebesar 1,839 dengan nilai signifikansi 0,068 lebih besar dari 0,05 (5 persen) yang mengindikasikan bahwa $\mathrm{H}_{4}$ ditolak. Hal ini berarti tingkat pengetahuan tidak berpengaruh pada minat memperoleh sertifikasi CA.

Hipotesis $1\left(\mathrm{H}_{1}\right)$ menyatakan bahwa semakin tinggi sikap terhadap perilaku, maka semakin tinggi minat mahasiswa akuntansi memperoleh sertifikasi CA. Berdasarkan hasil analisis data ditemukan bahwa sikap terhadap perilaku berpengaruh positif terhadap minat mahasiswa memperoleh sertifikasi CA. Tinggi-rendahnya sikap terhadap sertifikasi CA yang dimiliki oleh mahasiswa akan memengaruhi minatnya untuk memperoleh sertifikasi CA (Solikhah, 2014) dan (Sumaryono \& Sukanti, 2016). Hal ini karena sikap atau tanggapan seseorang pada sertifikasi CA dipengaruhi oleh adanya keyakinan dan tingkat harapan apakah memberikan manfaat, keuntungan ataupun tidak memberikan manfaat serta tidak menguntungkan bagi seorang individu terhadap nilai instrinsik, prospek karier dan pasar kerja Chartered Accountant. Semakin individu memiliki penilaian bahwa dengan memperoleh sertifikasi CA akan menghasilkan konsekuensi positif maka individu akan cenderung bersikap positif terhadap sertifikasi CA sehingga minatnya akan tinggi untuk memperoleh sertifikasi CA. Sebaliknya, semakin individu memiliki penilaian bahwa dengan memperoleh sertifikasi CA akan menghasilkan konsekuensi negatif maka individu akan cenderung bersikap negatif terhadap sertifikasi CA sehingga minatnya rendah untuk memperoleh sertifikasi CA. Hal tersebut sejalan dengan theory of planned behavior yang menjelaskan bahwa dalam proses pengambilan keputusan, sikap terhadap perilaku memiliki pengaruh terhadap minat seseorang untuk berperilaku (Ajzen, 1991).

Hasil penelitian ini searah dengan hasil penelitian Nisa, (2019a), Dewi et al., (2018), Sumaryono \& Sukanti, (2016), dan Solikhah, (2014) yang menyatakan bahwa sikap terhadap perilaku berpengaruh terhadap minat seseorang untuk memperoleh sertifikasi CA. Hal ini berarti bahwa semakin baik cara pandang seseorang terhadap sertifikasi CA, maka minat seseorang akan semakin meningkat untuk memperoleh sertifikasi $\mathrm{CA}$.

Hipotesis $2\left(\mathrm{H}_{2}\right)$ menyatakan bahwa semakin tinggi kepercayaan terhadap pengaruh sosial yang dirasakan, maka semakin tinggi minat mahasiswa akuntansi memperoleh sertifikasi CA. Berdasarkan hasil analisis data ditemukan bahwa norma subjektif berpengaruh positif pada minat mahasiswa memperoleh CA. Tinggi-rendahnya kepercayaan mahasiswa terhadap orang terdekat yang mendukung untuk memperoleh CA akan memengaruhi minatnya memperoleh CA Bekoe et al., (2018), Mihartinah \& Corynata, (2018), Permata et al., (2019), dan 
Wardani \& Januarti, (2015). Norma subjektif ditandai dengan adanya keyakinan normatif terhadap saran yang diberikan dari orang terdekat seperti dosen, keluarga dan teman. Lingkungan memiliki peran yang sangat penting dalam proses pengambilan keputusan suatu individu. Minat seorang individu akan lebih tinggi memperoleh sertifikasi CA apabila individu tersebut berada dalam lingkungan yang memiliki pengaruh positif terhadap sertifikasi CA dibandingkan dengan seorang individu dalam lingkungan yang kurang setuju untuk memperoleh sertifikasi CA sehingga minatnya akan lebih rendah untuk memperoleh sertifikasi CA. Hal tersebut sejalan dengan theory of planned behavior yang menjelaskan bahwa dalam proses pengambilan keputusan, norma subjektif memiliki pengaruh terhadap minat seseorang untuk berperilaku (Ajzen, 1991).

Hasil penelitian ini searah dengan hasil penelitian Permata et al., (2019), Mihartinah \& Corynata, (2018), Bekoe et al., (2018), Sumaryono \& Sukanti, (2016), dan Wardani \& Januarti, (2015) yang menyatakan bahwa norma subjektif berpengaruh terhadap minat seseorang untuk memperoleh sertifikasi CA. Hal ini berarti bahwa semakin banyak dukungan dari orang terdekat dan lingkungan yang mendukung untuk memperoleh CA, maka minat seseorang akan semakin meningkat memperoleh sertifikasi CA.

Hipotesis $3\left(\mathrm{H}_{3}\right)$ menyatakan bahwa semakin tinggi tingkat kontrol perilaku persepsian, maka semakin tinggi minat mahasiswa akuntansi memperoleh sertifikasi CA. Berdasarkan hasil analisis data ditemukan bahwa kontrol perilaku persepsian berpengaruh positif pada minat mahasiswa memperoleh CA. Tinggi-rendahnya keyakinan mahasiswa terhadap sedikitnya faktor penghambat untuk memperoleh CA akan memengaruhi minatnya memperoleh sertifikasi CA (Umar \& Bello, 2019). Tindakan seseorang dipengaruhi oleh suatu kontrol yang berupa keterampilan, kesempatan yang dimiliki untuk menunjukkan suatu perilaku, dan tersedianya sumber daya. Adanya keterampilan dan kemampuan akuntansi yang dikuasai mahasiswa serta adanya PMK No.216/PMK.01/2017 memberikan kesempatan, kemudahan bagi mahasiswa untuk memperoleh sertifikasi CA. Semakin mudah untuk memperoleh sertifikasi CA, maka semakin meningkat juga minat seseorang memperoleh sertifikasi CA. Hal tersebut sejalan dengan theory of planned behavior yang menjelaskan bahwa dalam proses pengambilan keputusan, kontrol perilaku persepsian memiliki pengaruh terhadap minat seseorang untuk berperilaku (Ajzen, 1991).

Hasil penelitian ini searah dengan hasil penelitian Umar \& Bello, (2019), Srirejeki et al., (2019), Sumaryono \& Sukanti, (2016), dan Solikhah, (2014) yang menyatakan bahwa kontrol perilaku persepsian berpengaruh pada minat seseorang untuk memperoleh CA. Hal ini berarti bahwa semakin banyak faktor pendukung dalam memperoleh CA, maka minat seseorang untuk memperoleh CA akan semakin meningkat.

Hipotesis $4\left(\mathrm{H}_{4}\right)$ menyatakan bahwa semakin tinggi tingkat pengetahuan mengenai CA, maka semakin tinggi minat mahasiswa akuntansi memperoleh sertifikasi CA. Berdasarkan hasil analisis data ditemukan bahwa tingkat pengetahuan tidak berpengaruh pada minat mahasiswa memperoleh CA. Tinggi-rendahnya tingkat pengetahuan yang dimiliki mahasiswa, tidak memengaruhi minatnya untuk memperoleh sertifikasi CA. Hal ini karena rata- 
rata mahasiswa masih belum memahami pentingnya profesionalisme seseorang dalam bidang akuntansi dengan memperoleh sertifikasi akuntan profesional untuk perkembangan karirnya di dunia kerja. Berdasarkan teori kognitif, faktor yang memengaruhi proses pengambilan suatu keputusan yaitu kemampuan berpikir dengan melibatkan pengetahuan. Pengetahuan tersebut diperoleh melalui proses interaksi secara berkesinambungan dengan lingkungan yang dijelaskan dalam teori ini. Dalam hal ini, proses pengambilan keputusan untuk memperoleh sertifikasi CA tidak hanya dilihat dari tingkat pengetahuan yang dimiliki, tetapi mungkin juga dari faktor informasi lainnya seperti pengalaman ataupun pemberitaan melalui media masa.

Hasil penelitian ini searah dengan hasil penelitian Sumaryono \& Sukanti, (2016) yang menyatakan bahwa tingkat pengetahuan mengenai CA tidak berpengaruh pada minat mahasiswa untuk memperoleh sertifikasi CA. Berdasarkan pengamatan yang dilakukan oleh peneliti, hasil penelitian yang menggambarkan penolakan pada $\mathrm{H}_{4}$ juga dapat dikarenakan intensitas jawaban responden pada masing-masing pernyataan yang mewakili setiap indikator dalam tingkat pengetahuan mengenai CA. Salah satunya adalah indikator tingkat pengetahuan mengenai PMK No. 216/PMK.01/2017 terkait dengan CA, yang dimana mahasiswa cenderung memiliki pengetahuan yang kurang dan rasa ingin tahu yang rendah terhadap peraturan tersebut.

\section{SIMPULAN}

Berdasarkan hasil penelitian menunjukkan bahwa sikap terhadap perilaku berpengaruh positif pada minat mahasiswa memperoleh CA. Hal ini mengindikasikan bahwa semakin tinggi sikap positif atau tanggapan positif mahasiswa terhadap CA, maka semakin tinggi minatnya memperoleh CA. Norma subjektif berpengaruh positif pada minat mahasiswa memperoleh CA. Hal ini mengindikasikan bahwa semakin tinggi kepercayaan mahasiswa terhadap orang terdekat yang mendukung untuk memperoleh CA, maka semakin tinggi minat mahasiswa memperoleh CA. Kontrol perilaku persepsian berpengaruh positif pada minat mahasiswa memperoleh CA. Hal ini mengindikasikan bahwa semakin tinggi keyakinan akan banyaknya faktor pendukung untuk memperoleh $\mathrm{CA}$, maka semakin tinggi minat mahasiswa memperoleh CA. Tingkat pengetahuan mengenai CA tidak berpengaruh pada minat mahasiswa memperoleh CA. Hal ini berarti pengetahuan mahasiswa terhadap isi dari Peraturan Menteri Keuangan No. 216/PMK.01/2017 tentang Akuntan Beregister Negara terkait dengan sertifikasi CA tidak memengaruhi minat mahasiswa memperoleh CA.

Keterbatasan penelitian ini yaitu sampel penelitian terbatas pada mahasiswa S1 Akuntansi angkatan 2017 FEB UNUD, penelitian selanjutnya disarankan mempertimbangkan untuk memperluas responden dan memperhatikan pemilihan responden agar mendapatkan validitas jawaban yang lebih baik, misalnya dari mahasiswa PPAk sebagai responden dalam penelitian. Selain itu, hasil penelitian menunjukkan bahwa indikator pengetahuan terhadap PMK No.216/PMK.01/2017 tentang Akuntan Beregister Negara terkait dengan CA serta cara atau syarat untuk mendapatkan sertifikasi CA memiliki nilai yang kecil dalam indikator penentu tingkat pengetahuan mengenai CA. Berdasakan 
hasil tersebut, maka disarankan untuk instansi perguruan tinggi khususnya Fakultas Ekonomi dan Bisnis Universitas Udayana agar lebih mensosialisasikan tentang Peraturan Menteri Keuangan tersebut serta cara ataupun syarat untuk mendapatkan sertifikasi CA.

\section{REFERENSI}

Agusalim, L., \& Pohan, F. S. (2017). Globalisasi Ekonomi dan Pengaruhnya Terhadap Kemiskinan dan Ketimpangan Pendapatan di Indonesia. Proceeding Konferensi Nasional Dan Call for Paper, 103-119. https://doi.org/10.5281/zenodo.1037618

Ajzen, I. (1991). The Theory of Planned Behavior. Organizational Behavior and Human Decision Processes, 50(2), 179-211. https://doi.org/10.1016/07495978(91)90020-T

Akter, M., \& Siraj, M. M. (2018). Factors Affecting Undergraduate Students ' Intention to Become a Chartered Accountant in Bangladesh. Asian Journal of $\begin{array}{llll}\text { Finance } & \mathcal{E} & \text { Accounting, } & \text { 428-439. }\end{array}$ https://doi.org/10.5296/ajfa.v10i1.13259

Alam, M. Z., Kousar, S., \& Rehman, C. A. (2019). Role of Entrepreneurial Motivation on Entrepreneurial Intentions and Behaviour : Theory of Planned Behaviour Extension on Engineering Students in Pakistan. Journal of Global Entrepreneurship Research, 9(50), 1-20. https://doi.org/https://doi.org/10.1186/s40497-019-0175-1

Bekoe, R. A., Owusu, G. M. Y., Ofori, C. G., Anderson, A. E., \& Welbeck, E. E. (2018). Attitudes Towards Accounting and Intention to Major in Accounting : a Logistic Regression Analysis. Journal of Accounting in Emerging Economies, 8(4), 459-475. https://doi.org/10.1108/JAEE-01-20180006

Brouard, F., Bujaki, M., Durocher, S., \& Neilson, L. C. (2016). Professional Accountants ' Identity Formation : An Integrative Framework. Journal of Business Ethics. https:/ / doi.org/10.1007/s10551-016-3157-z

Coe, M. (2016), "Factors that influence a student's intention to sit for the CPA exam", CPA Journal, Vol. 86 No. 8, pp. 18-20.

Dalci, I., \& Ozyapici, H. (2016). Cultural Values and Students' Intentions of Choosing Accounting Career. Journal of Financial Reporting and Accounting, 1-20. https://doi.org/https://doi.org/10.1108/JFRA-09-2016-0072

Dewi, I. G. A. R. P., Putri, P. Y. A., \& Dewi, C. I. R. S. (2018). Niat Untuk Mengambil Sertifikasi Akuntan Dengan Pengujian Theory Of Planned Behavior Dan Teori Motivasi. Jurnal Ilmiah Akuntansi, 3(2), 171-192.

Febryanti, P. A. B., \& Suardana, K. A. (2018). Pengaruh Motivasi dan Pengetahuan UU No . 5 Tahun 2011 Pada Minat Mahasiswa Akuntansi Mengikuti Ppak. E-Jurnal Akuntansi Universitas Udayana, 25(5), 357-383. https://doi.org/https://doi.org/10.24843/EJA.2018.v25.i01.p14

Gayatri, Widanaputra, \& Suprasto, B. (2016). Pemahaman Mahasiswa Jurusan Akuntansi Atas Penerapan International Financial Reporting Standard Dalam Menghadapi Masyarakat Ekonomi ASEAN. Jurnal Ilmiah Akuntansi Dan Bisnis, 11(1), 11-16.

Ghozali, I. (2018). Aplikasi Analisis Multivariate dengan Program IBM SPSS 25 (Edisi 
9). Semarang: Universitas Diponegoro.

Grace N, O., \& Ekele, J. I. (2018). The Role of Chartered Accountants in Eradicating Curruption in Nigeria. Journal of Humanities and Social Sciences, 20(1), 45-50.

Hasim, F., Darmayanti, N., \& Dientri, A. M. (2020). Analysis of Factors that Influence Accounting Students Choose Career As A Public Accountant. Journal Of Auditing, Finance, And Forensic Accounting, 8(1), 19-26. https://doi.org/https://doi.org/10.21107/jaffa.v8i1.6733

Islamylia, \& Mutia, E. (2016). Pengaruh Sikap, Norma Subjektif, Kontrol Perilaku, Motivasi Spiritual Terhadap Minat Mahasiswa Akuntansi Dalam Memilih Konsentrasi Akuntansi Syariah Di Fakultas Ekonomi Universitas Syiah Kuala. Jurnal Ilmiah Mahasiswa Ekonomi Akuntansi (JIMEKA), 1(1), 192-203.

Kusumastuti, R., \& Waluyo, I. (2013). Pengaruh Motivasi Dan Pengetahuan UU No. 5 Tahun 2011 Tentang Akuntan Publik Terhadap Minat Mahasiswa Akuntansi Mengikuti Pendidikan Profesi Akuntansi (PPAk). Jurnal Nominal, 2(2), 1-30. https://doi.org/https:// doi.org/10.21831/nominal.v2i2.1662

Menteri Keuangan. Peraturan Menteri Keuangan Republik Indonesia Nomor 216/PMK.01/2017 Tentang Akuntan Beregister. (2017). Indonesia.

Mihartinah, D., \& Corynata, I. (2018). Pengaruh Sikap Terhadap Perilaku, Norma Subjektif, Dan Kontrol Perilaku Persepsian Terhadap Niat Mahasiswa Akuntansi Untuk Mengambil Sertifikasi Chartered Accountant. Jurnal Akuntansi, 8(2), 77-87.

Nisa, S. (2019a). Pengaruh Motivasi Dan Sikap Terhadap Minat Mahasiswa Akuntansi Untuk Mengambil Profesi Chartered Accountant Pada Universitas Islam Swasta Di Kota Medan. Jurnal Mutiara Akuntansi, 04(1), $49-62$.

Nisa, S. (2019b). Pengaruh Tingkat Pemahaman Dan Motivasi Terhadap Minat Mahasiswa Akuntansi Untuk Mengambil Profesi Chartered Accountant Pada Universitas Islam Swasta Di Kota Medan. Jurnal Riset Akuntansi Multiparadigma (JRAM), 6(1), 64-73.

Owusu, G. M. Y., Obeng, V. A., Ofori, C. G., Kwakye, T. O., \& Bekoe, R. A. (2018). What Explains Student's Intentions to Pursue a Certified Professional Accountancy Qualification? Meditari Accountancy Research, 26(2), 284-304. https://doi.org/10.1108/MEDAR-06-2016-0065

Permata, F. P., Setyorini, C. T., \& Sudjono. (2019). Pengaruh Norma Subjektif Dan Motivasi Terhadap Minat Sertifikasi Akuntansi. Journal Of Accounting and Business, 03(01), 55-57.

Pratama, A. (2017). Why Do Accounting Students Choose a Career in Accountancy? An Exploratory Study in Bandung City, West Java , Indonesia. Review of Integrative Business and Economics Research, 6(2), 393-407.

Seni, N. N. A., \& Ratnadi, N. M. D. (2017). Theory of Planned Behavior Untuk Memprediksi Niat Berinvestasi. E-Jurnal Ekonomi Dan Bisnis Universitas Udayana, 6(12), 4043-4068. https:// doi.org/10.24843/eeb.2017.v06.i12.p01

Solikhah, B. (2014). An Application of Theory of Planned Behavior Towards CPA Career in Indonesia. Procedia - Social and Behavioral Sciences, 164(August), 397-402. https://doi.org/10.1016/j.sbspro.2014.11.094

Srirejeki, K., Supeno, S., \& Faturahman, A. (2019). Understanding the Intentions 
of Accounting Students to Pursue Career as a Professional Accountant. Binus Business Review, 10(1), 11-19. https:/ / doi.org/10.21512/bbr.v10i1.5232 Sugiyono. (2019). Metode Penelitian Kuantitatif, Kualitatif, dan RED. Bandung: Alfabeta.

Sumaryono, \& Sukanti. (2016). Faktor-Faktor Yang Mempengaruhi Niat Mahasiswa Akuntansi Untuk Mengambil Sertifikasi Chartered Accountant. Jurnal Profita, 4(7), 1-20.

Thorne, L. (2016). Discussion of " A Theoretical Framework of Professional Accountants " Identity Formation and Directions for Future Research ". Journal of Business Ethics, 142(2), 239-240. https://doi.org/10.1007/s10551016-3145-3

Ticoi, C. florina, \& Albu, N. (2018). What factors affect the choice of accounting as a career? The case of Romania. Accounting and Management Information Systems, 17(1), $137-152$. https://doi.org/http://dx.doi.org/10.24818/jamis.2018.01007 What

Ulfah, R., Jaharadak, A. A., \& Khatibi, A. A. (2019). Motivational Factors Influencing MSU Accounting Students to Become a Certified Public Accountant (CPA). Management Science Letters, 9(2019), 1675-1684. https:// doi.org/10.5267/j.msl.2019.5.020

Umar, I., \& Bello, M. S. (2019). The Relationship between Accounting Students ' Self -Efficacy Beliefs, Outcome Expectations on Intention to Become Chartered Accountants. Journal of Economics, Business and Management, 2(7), 376-381.

Wardani, G. A. S., \& Januarti, I. (2015). Niat Untuk Mengambil Chartered Accountant Dengan Theory Of Planned Behavior. Jurnal Akuntansi $\mathcal{E}$ Auditing, 12(2), 140-159.

Wen, L., Hao, Q., \& Bu, D. (2015). Understanding the Intentions of Accounting Students in China to Pursue Certified Public Accountant Designation. Accounting Education: An International Journal, 24(4), 341-359. https://doi.org/10.1080/09639284.2015.1051561 